\title{
GAMBARAN PENGETAHUAN DAN SIKAP REMAJA PUTRI TERHADAP PERSONAL HIGIENE SAAT MENSTRUASI DI SMP N 19 KOTA JAMBI TAHUN 2018
}

\author{
Liza \\ Dosen Akbid Budi Mulia Jambi \\ Email :lizaboulqiah41290@gmail.com
}

\begin{abstract}
Health care and hygiene are things that are widely discussed in the community. For teenagers this is considered not important because they do not know the impact that will be caused if this is not done properly, especially during menstruation. While during menstruation issued not only blood cells but also epithelial cells of the uterine wall. In the world, the incidence of reproductive infections is around 2.3 million per year, mostly teenagers. According to the percentage of schools with the third highest number of students found in SMP N 19 Jambi City, with a target number of VIII grade students of 138 students. This study aims to determine the description of knowledge and attitudes of young women towards personal hygiene during menstruation at SMP N 19 Jambi City in 2018. The population in this study was VIII grade students totaling 138 female students. The number of samples is 58 students taken randomly using simple random sampling technique. This study uses univariate analysis to describe the frequency distribution table of the studied variables. The results of data analysis showed that respondents who had poor knowledge were 38 respondents $(65.5 \%)$, and respondents with negative attitudes were 32 respondents $(55.2 \%)$. It is hoped that in future schools will pay more attention to the knowledge of students about adolescent reproductive health by providing reading books and occasionally working with the nearest health center to conduct counseling.
\end{abstract}

Keywords: behavior, knowledge, menstruation, personal hygiene, teenager

\begin{abstract}
ABSTRAK
Perawatan kesehatan dan kebersihan adalah hal-hal yang banyak dibahas di masyarakat. Untuk remaja ini dianggap tidak penting karena mereka tidak tahu dampak yang akan ditimbulkan jika hal ini tidak dilakukan dengan benar, terutama saat menstruasi. Sementara saat menstruasi dikeluarkan tidak hanya sel darah tetapi juga sel epitel dinding rahim. Di dunia, kejadian infeksi reproduksi adalah sekitar 2,3 juta per tahun, sebagian besar remaja. Menurut persentase sekolah dengan jumlah siswa tertinggi ketiga ditemukan di SMP N 19 Kota Jambi, dengan target jumlah siswa kelas VIII sebanyak 138 siswa. Penelitian ini bertujuan untuk mengetahui gambaran pengetahuan dan sikap remaja putri terhadap kebersihan diri saat menstruasi di SMP N 19 Kota Jambi tahun 2018. Populasi dalam penelitian ini adalah siswa kelas VIII yang berjumlah 138 siswa perempuan. Jumlah sampel adalah 58 siswa yang diambil secara acak menggunakan teknik simple random sampling. Penelitian ini menggunakan analisis univariat untuk menggambarkan tabel distribusi frekuensi dari variabel yang diteliti. Hasil analisis data menunjukkan bahwa responden yang memiliki pengetahuan buruk adalah 38 responden (65,5\%), dan responden dengan sikap negatif adalah 32 responden $(55,2 \%)$. Diharapkan bahwa di masa mendatang sekolah akan lebih memperhatikan pengetahuan siswa tentang kesehatan reproduksi remaja dengan
\end{abstract}


menyediakan buku bacaan dan kadang-kadang bekerja dengan pusat kesehatan terdekat untuk melakukan konseling.

Kata kunci: menstruasi, pengetahuan, personal hygiene,remaja, sikap

\section{PENDAHULUAN}

Perawatan kesehatan dan kebersihan adalah hal yang banyak dibicarakan dalam masyarakat. biasanya hal ini diajarkan oleh orangtua sejak kita masih kecil. Tetapi karena orang tua sering kali merasa tidak nyaman membicarakan masalah pendidikan seksual biasanya masalah kesehatan dan kebersihan yang dibicarakan hanya menyangkut hal yang umum saja, sedangkan urusan kesehatan organ reproduksi jarang kita dapatkan dari mereka (Sarwono. 2006:115). Menurut WHO dan beberapa badan dunia lainnya tahun 1998, menghimbau semua Negara Asia Tenggara agar memberikan komitmennya untuk memperhatikan dan melindungi kebutuhan remaja akan informasi, keterampilan, pelayanan dan lingkungan yabg umum dan kesehatan reproduksi remaja (Soetjiningsih, 2004).

Di dunia, angka kejadian infeksi alat reproduksi diperhatikan sekitar 2,3 juta per tahun 1,2 juta diantaranya ditemukan di Negara berkembang, sedangkan jumlah penderita baru sekitar 5 juta per tahun dan terdapat dinegara berkembang sekita 3 juta. Kesehatan reproduksi merupakan bagian paling penting dari program kesehatan mengingat pengaruhnya terjadi setiap orang dan mencakup hanya aspek kehidupan, sejak dalam kandungan sampai usia lanjut (Mafhiasawah, 2010). Di Indonesia pelayanan kesehatan reproduksi mencakup 4 komponen esensial yang mapu memberikan hasil yang efektif dan efisien. Adapun 4 komponen antara lain pelayanan kesehatan rweproduksi esensial (PKRE) yaitu kesehatan ibu dan bayi baru lahir, keluarga berencana, kesehatan reproduksi remaja (KRR) dan pencegahan atau penanggulangan Penyakit Menular Seksual (PMS) termasuk HIV/AIDS (Bobak, 2004:827).

Beberapa penyakit ginekologi dan gangguan alat reproduksi perempuan merupakan suatu masalah serius dala masyarakat seperti kemandulan, keputihan, dan kanker rahim. Dinegara maju insiden terjadinya infeksi 87 per 100.000 angka kematiannya kira-kira 27 per 100.000 (Andira, 2010:75). Remaja diDefinisikan sebagai masa peralihan dari masa kanak-kanak ke masa dewasa, dimana terjadi perubahan psikologi dan kognitif (Soetjiningsih, 2004). Selama perkembangan menuju dewasa, tubuh berkembangsan secara terus-menerus. Keseluruhan frekuensi perubahan terjadi dengan cepat sebelum lahir, selama masa bayi, dan saat pubertas (Cristiana, 2004). Menurut WHO (1995) seperlima dari penduduk dunia adalah remaja berusia 10-19 tahun. Sekitar $15 \%$ populasi di Asia Pasifik dimana penduduk merupakan $60 \%$ dari penduduk dunia, seperlimanya adalah remaja umur 10-19 tahun (Mafhiasawah, 2010).

Setelah melakukan survey awal pada tanggal 05 Januari 2017, didapat jumlah siswi kelas VIII SMP N 19 Kota Jambi berjumlah 138 siswi. Setelah mewawancarai 10 siswi SMP N 19 Kota Jambi melalui pertanyaan berapa kali mengganti pembalut dalam sehari, mereka menjawab jika darahnya tidak terlalu banyak cukup satu kali. Hal ini tidak sesuai dengan teori yaitu penggantian pembalut saat menstruasi minimal 4 jam sekali (Sunyoto, 2015). Hanya $30 \%$ yang bisa mengetahui 
tentang personal higiene saat menstruasi yang berarti di SMP N 19 Kota Jambi masih kurangnya pengetahuan dan sikap siswi tentang personal higiene saat menstruasi.

\section{METODE PENELITIAN}

Penelitian ini bersifat deskriptif yang dilakukan dengan tujuan untuk menggambarkan tentang suatu keadaan secara objektif (Notoatmodjo, 2010:26). Penelitian ini dilakukan untuk mengetahui gambaran pengetahuan dan sikap remaja putri tentang personal higiene saat menstruasi di SMPN 19 Kota Jambi Tahun 2018.

\section{HASIL PENELITIAN}

Analisis ini dilakukan untuk presentase dari variabel independen yaitu pengetahuan dan sikap.

\section{Pengetahuan}

Dari hasil penelitian, pengetahuan responden dikategorikan menjadi 2 yaitu responden berpengetahuan baik (jika hasil presentase $<76 \%$ jawaban yang benar pengetahuan ibu kurang baik), responden berpengetahuan baik (jika hasil presentase $\geq 76 \%$ jawaban yang benar pengetahuan ibu baik). mengetahui distribusi frekuensi dan Tabel 1. Distribusi Pengetahuan siswi di SMP N 19 Kota Jambi (n = 58)

\begin{tabular}{|c|c|c|c|c|c|}
\hline No. & Pertanyaan & Tahu & $\%$ & $\begin{array}{l}\text { Tidak } \\
\text { Tahu }\end{array}$ & $\%$ \\
\hline 1. & Pengertian personal higiene & 33 & 56,8 & 25 & 43,1 \\
\hline 2. & Pengertian Menstruasi & 54 & 93,1 & 4 & 6,8 \\
\hline 3. & $\begin{array}{l}\text { Pengertian personal higiene saat } \\
\text { menstruasi }\end{array}$ & 45 & 77,58 & 13 & 22,41 \\
\hline 4. & $\begin{array}{l}\text { Yang bukan termasuk tujuan personal } \\
\text { higiene }\end{array}$ & 51 & 87,93 & 7 & 12,06 \\
\hline 5. & $\begin{array}{l}\text { Karena peningkatan hormone dan tubuh } \\
\text { menjadi mudah sekali berkeringat, ketika } \\
\text { menstruasi dianjurkan untuk mandi } \\
\text { minimal berapa kali }\end{array}$ & 52 & 89,65 & 6 & 10,34 \\
\hline 6. & $\begin{array}{l}\text { Saat menstruasi dianjurkan untuk } \\
\text { mengganti pembalut minimal berapa kali }\end{array}$ & 17 & 29,3 & 41 & 70,68 \\
\hline 7. & $\begin{array}{l}\text { Bagaimana cara membersihkan vagina } \\
\text { yang benar setelah buang air kecil } \\
\text { (BAK) maupun buang air besar (BAB) }\end{array}$ & 13 & 22,4 & 45 & 77,58 \\
\hline 8. & $\begin{array}{l}\text { Mengapa kuku saat menstruasi } \\
\text { sebaiknya tidak panjang dan selalu } \\
\text { bersih }\end{array}$ & 51 & 87,9 & 7 & 12,06 \\
\hline 9. & $\begin{array}{l}\text { Mengapa saat menstruasi sebaiknya } \\
\text { tidak menggunakan calana yang terlalu } \\
\text { ketat dan tidak menyerap keringat }\end{array}$ & 41 & 70,68 & 17 & 29,31 \\
\hline 10. & $\begin{array}{l}\text { Apa salah satu dampak akibat kurangnya } \\
\text { personal higiene saat menstruasi }\end{array}$ & 22 & 37,93 & 36 & 62,06 \\
\hline
\end{tabular}


Dari tabel $1 \mathrm{di}$ atas pertanyaan tentang saat menstruasi dianjurkan untuk mengganti pembalut minimal berapa kali 41 responden menjawab salah $(70,68 \%)$, pertanyaan bagaimana cara membersihkan vagina yang benar setelah buang air kecil (BAK) maupun buang air besar (BAB) 45 responden menjawab salah $(77,58 \%)$, pertanyaan tentang apa salah satu dampak akibat kurangnya personal higiene saat menstruasi 36 responden menjawab salah(62,06\%). Dari hasil penelitian terhadap 58 responden dari tingkat pengetahuan dapat dikelompokkan menjadi 2 kategori, kurang baik dan baik.

Tabel 2 Distribusi Frekuensi Pengetahuan Siswi Terhadap Personal Higiene Saat Menstruasi di SMP N 19 Kota Jambi Bulan April Tahun 2018 (n=58)

No. $\quad$ Pengetahuan Siswi Tentang Personal Higiene Saat $\quad$ n $\%$ Menstruasi

\begin{tabular}{llcc}
\hline 1. & Kurang Baik & 38 & 65,5 \\
2. & Baik & 20 & 34,5 \\
\hline & & 58 & 100 \\
\hline
\end{tabular}

Berdasarkan tabel 2 bahwa jumlah distribusi frekuensi responden berdasarkan tingkat pengetahuan responden yang berpengetahuan kurang baik sebanyak 38 responden $(65,5 \%$
Dari hasil penelitian terhadap 58 responden di bagi menjadi 2 kategori yaitu ibu hamil yang memiliki motivasi baikskor $\geq$ median dan ibu hamil yang memiliki motivasi kurang baik skor $<$ median.

\section{Sikap}

\section{Tabel 3. Distribusi Frekuensi Sikap siswi di SMP N 19 Kota Jambi $(n=58)$}

\begin{tabular}{|c|c|c|c|c|c|c|c|c|c|}
\hline No. & Pertanyaan & SS & $\%$ & $\mathrm{~S}$ & $\%$ & TS & $\%$ & STS & $\%$ \\
\hline 1. & $\begin{array}{l}\text { Saat menstruasi terserah } \\
\text { mengganti pembalut berapa kali } \\
\text { yang penting tidak tembus }\end{array}$ & 51 & 87,93 & 8 & 13,79 & 0 & 0 & 0 & 0 \\
\hline 2. & $\begin{array}{l}\text { Saat menstruasi tidak } \\
\text { diperkenankan memotong kuku }\end{array}$ & 58 & 100 & 0 & 0 & 0 & 0 & 0 & 0 \\
\hline 3. & $\begin{array}{l}\text { Saat menstruasi ganti pembalut } \\
\text { cukup } 2 \text { kali sehari }\end{array}$ & 26 & 44,82 & 1 & 1,72 & 21 & 36,20 & 10 & $\begin{array}{l}17, \\
24\end{array}$ \\
\hline 4. & $\begin{array}{l}\text { Saat menstruasi sebaiknya } \\
\text { meggunakan celana dalam yang } \\
\text { ketat agar pembalut tidak geser }\end{array}$ & 0 & 0 & 42 & 72,41 & 16 & 27,58 & 0 & 0 \\
\hline 5. & $\begin{array}{l}\text { Membersihkan alat kelamin } \\
\text { setelah BAK/BAB sebaiknya } \\
\text { menggunakan air mengalir dari } \\
\text { arah depan ke belakang }\end{array}$ & 0 & 0 & 58 & 100 & 0 & 0 & 0 & 0 \\
\hline 6. & $\begin{array}{l}\text { Jika terasa lembab sebaiknya } \\
\text { celana dalam diganti }\end{array}$ & 0 & 0 & 0 & 0 & 56 & 96,50 & 2 & $\begin{array}{c}3,4 \\
4\end{array}$ \\
\hline
\end{tabular}




\begin{tabular}{lllllllllc}
\hline 7. & $\begin{array}{l}\text { Saat menstruasi tidak boleh } \\
\text { terlalu sering mencuci rambut }\end{array}$ \\
8. & 39,65 & 34 & 58,62 & 0 & 0 & 1 & 1,7 \\
$\begin{array}{l}\text { Menstruasi hari ke lima ganti } \\
\text { pembalutnya cukup 1 kali sehari }\end{array}$ & 9 & 15,51 & 45 & 77,58 & 0 & 0 & 4 & 6,8 \\
$9 . \quad \begin{array}{l}\text { Setelah menstruasi sebaiknya } \\
\text { menggunting rambut di sekitar } \\
\text { kemaluan }\end{array}$ & 0 & 0 & 19 & 32,75 & 39 & 67,24 & 0 & 0 \\
10 & $\begin{array}{l}\text { Kuku yang kotor adalah tempat } \\
\text { kuman jadi harus di potong }\end{array}$ & 57 & 98,27 & 0 & 0 & 1 & 1,72 & 0 & 0 \\
\hline
\end{tabular}

Dari tabel 3 dapat diketahui sebagian besar responden memiliki sikap yang kurang baik untuk melakukan personal higiene yang benar saat menstruasi, yaitu 51 orang responden menjawab sangat setuju saat menstruasi terserah mengganti pembalut berapa kali yang penting tidak tembus $(87,93 \%)$, 58 orang responden menjawab sangat setuju saat menstruasi tidak diperkenankan memotong kuku (100 \%), 26 Orang responden menjawab sangat setuju saat menstruasi ganti pembalut cukup 2 kali sehari $(44,82 \%), \quad 42$ orang responden menjawab setuju saat menstruasi sebaiknya meggunakan celana dalam yang ketat agar pembalut tidak geser $(72,41 \%), \quad 56$ orang responden menjawab tidak setuju jika terasa lembab sebaiknya celana dalam diganti $(96,50 \%), 34$ responden menjawab setuju Saat menstruasi tidak boleh terlalu sering mencuci rambut Saat menstruasi tidak boleh terlalu sering mencuci rambut $(58,62 \%), 45$ orang responde menjawab setuju menstruasi hari ke lima ganti pembalutnya cukup 1 kali sehari $(77,58 \%), 39$ orang responden menjawab tidak setuju setelah menstruasi sebaiknya menggunting rambut di sekitar kemaluan (67,24\%). Dari hasil penelitian terhadap 58 responden dari sikap siswi dapat dikelompokkan menjadi 2 kategori, sikap negatif dan positif.

Tabel 4 Distribusi Frekuensi Sikap Siswi Terhadap Personal Higiene Saat Menstruasi di SMP N 19 Kota Jambi Bulan April Tahun 2018 (n=58)

\begin{tabular}{|c|c|c|c|}
\hline No. & Personal Higiene Saat Menstruasi & $\mathrm{n}$ & $\%$ \\
\hline 1. & Sikap Negatif & 32 & 55,2 \\
\hline 2. & Sikap Positif & 26 & 44,8 \\
\hline & Total & 58 & $100 \%$ \\
\hline
\end{tabular}

Berdasarkan tabel 4 terlihat responden yang mempunyai sikap negatif terhadap personal higiene saat menstruasi 32 orang $(55,2 \%)$.
PEMBAHASAN

Gambaran Pengetahuan Siswi Terhadap Personal Higiene Saat Menstruasi

Pengetahuan dikelompokkan menjadi dua kategori yaitu antara hasil 
presentase $<76 \%$ jawaban yang salah berarti tingkat pengetahuan siswi kurang baik dan hasil presentase $\geq 76$ $\%$ jawaban yang benar berarti tingkat pengetahuan siswi baik. Dari hasil analisa univariat diketahui sebagian responden mempunyai pengetahuan kurang baik. Pengetahuan responden tentang pengetahuan meliputi kemampuan untuk menjawab materi tentang pengertian menstruasi, pengertian personal higiene, pengertian personal higiene saat menstruasi, tujuan personal higiene, dampak jika tidak melakukan personal higiene dengan baik saat menstruasi dan cara melakukan personal higiene yang baik saat menstruasi.

Berdasarkan hasil penelitian dapat disimpulkan kurangnya pengetahuan responden tentang personal higiene saat menstruasi terutama pada manfaat dan dampak yang akan terjadi membuat siswi tidak mau melakukan personal higiene yang baik saat menstruasi sehingga membutuhkan peran aktif petugas kesehatan dalam memberikan pelayanan dan dorongan kepada siswi agar mereka mau melakukan personal higiene dengan baik saat menstruasi, karena pengetahuan individu tentang penyakit dan pencegahannya akan mempengaruhi sikap individu untuk berperilaku sehat.

Pengetahuan adalah hasil penginderaan manusia, atau hasil tahu seseorang terhadap objek melalui indera yang dimilikinya (mata, hidung, telinga, dan sebagainya). Dengan sendirinya pada waktu penginderaan sehingga menghasilkan pengetahuan tersebut sangat dipengaruhi oleh intensitas perhatian dan persepsi terhadap objek. Sebagian besar pengetahuan seseorang diperoleh melalui penginderaan dari mata dan telinga (Notoatmodjo, 2010:27). Dari hasil uraian jawaban kuesioner pada penelitian yang dilakukan menunjukkan bahwa sebagian besar responden tidak tahu berapa kali minimal mengganti pembalut dalam sehari (24 jam). Bagi sebagian responden, mereka akan mengganti pembalut saat "tembus", jika tidak tembus mereka cenderung malas untuk menggantinya. Padahal menurut teori penggantian pembalut minimal dua kali sehari pada saat menstruasi minimal 3-4 jam dalam sehari dan jangan membiarkan pembalut lengket seharian, pembalut yang sudah dipakai dibersihkan dengan benar sampai bersih dengan mencucinya sampai tidak tersisa lagi darah dan kemudian buang ke tempat sampah.

Sebagian responden tidak tahu cara membersihkan alat kelamin yang benar setelah buang air kecil (BAK) dan sesudah buang air besar (BAB) saat menstruasi. Pembersihan vagina yaitu pembilasan dengan air bersih dari arah depan ke belakang dan baiknya menggunakan air mengalir , mencuci tangan terlebih dahulu saat pertama kali membasuh area vagina, dan pastikan kuku tidak panjang karena akan melukai vagina (Mafhiasawah, 2010). Hal ini juga perlu diperhatikan karena letak antara vagina dan anus yang berdekatan. Salah dalam cara membersihkan terutama saat $\mathrm{BAB}$ dapat membawa kotoran yang ada pada anus ke daerah vagina. 
Responden juga tidak tahu dampak jika tidak melakukan personal higiene saat menstruasi.Saat menstruasi rahim tidak hanya mengeluarkan darah tetapi jaringan endometrium yang mengalami peluruhan, secret servik uteri, dan secret endometrium Kondisi ini merupakan media dan waktu yang sangat baik bagi kuman untuk berkembang biak, akibatnya akan timbul penyakit-penyakit yang disebabkan infeksi bakteri seperti flour albus, vaginitis, vulvitis, endometriosis, radang panggul dan kanker (Asep Sufyan, 2011:65).

\section{Gambaran Sikap Siswi Terhadap Personal Higiene Saat Menstruasi}

Sikap dikelompokkan menjadi dua kategori yaitu positif dan negatif, untuk mengetahui sikap responden menggunakan mean. Nilai mean 21,55. Dari hasil data univariat diketahui jumlah responden yang mempunyai sikap negative terhadap personal higiene saat menstuasi sebanyak 32 orang $(55,2 \%)$. Dari hasil penelitian ini menunjukkan bahwa sebagian responden merasa tidaki nyaman jika harus melakukan personal higiene yang benar saat menstruasi karena sebagian responden merasa personal higiene yang benar saat menstruasi tidak begitu penting dan akibat yang ditimbulkanpun tidak begitu berbahaya.

Responden yang mempunyai sikap positif karena dipengaruhi oleh lingkungan dan pengetahuan. Sesuai dengan teori Lawrence Green "pengaruh orang lain yang dianggap penting. Pada umumnya, individu cenderung memiliki sikap yang konformis yang searah dengan sikap orang yang dianggap penting". Sebagian besar responden tidak tahu mengganti pembalut berapa kali sehari, sementara menurut teori Penggantian pembalut minimal dua kali sehari pada saat menstruasi minimal 3-4 jam dalam sehari dan jangan membiarkan pembalut lengket seharian, pembalut yang sudah dipakai dibersihkan dengan benar sampai bersih dengan mencucinya sampai tidak tersisa lagi darah dan kemudian buang ke tempat sampah. Responden menjawab setuju saat menstruasi tidak diperkenankan memotong kuku dan mencuci rambut terlalu sering, hal ini mungkin uga dipengaruhi mitos yang beredar di masyarakat juga karena mereka tidak tahu jika kuku panjang dapat melukai vagina sehingga menyebabkan iritasi pada vagina. Sementara mencuci rambut justru dianjurkan menggunakan air hangat 2 hari sekali agar rambut bersih karena saat menstruasi keringat yang dikeluarkan lebih banyak (Mafhiasawah, 2010).

Responden menjawab setuju saat menstruasi sebaiknya meggunakan celana dalam yang ketat agar pembalut tidak geser. Hal ini tidak sesuai dengan teori yaitu memakai celana dalam sebaiknya yang menyerap keringat dan tidak terlalu ketat untuk menghindari agar vagina tidak lembab, jika vagina lembab ini merupakan tempat yang sangat baik bagi kuman untuk berkembangbiak (Mafhiasawah, 2010).

Responden menjawab tidak setuju setelah menstruasi sebaiknya menggunting rambut di sekitar 
kemaluan. Sementara menurut teori bulu pubis yang lebat, tak beraturan dan lembab adalah tempat favorit bagi sarang kuman oleh karena itu pubis sebaiknya dirapikan (Harahap, 2011). Selain itu juga akan membuat kita lebih nyaman, karena pubis yang terlalu panjang juga dapat menimbulkan rasa gatal, lembab dan bau.

\section{SIMPULAN}

Hasil penelitian yang dilakukan secara univariat maupun uji statistik di dapat kesimpulan gambaran pengetahuan dan sikap remaja putri terhadap personal higiene saat menstruasi di SMP N 19 Kota Jambi Tahun 2017 :

1. Sebagian besar responden mempunyai pengetahuan kurang baik tentang personal higiene pada saat menstruasi

2. Sebagian besar responden mempunyai sikap negative terhadap personal higiene saat menstruasi

\section{SARAN}

Diharapkan bahwa di masa mendatang sekolah akan lebih memperhatikan pengetahuan siswa tentang kesehatan reproduksi remaja dengan menyediakan buku bacaan dan kadang-kadang bekerja dengan pusat kesehatan terdekat untuk melakukan konseling

\section{DAFTAR PUSTAKA} Ginekologi dan Gangguan Kesehatan Reproduksi. Saufa:Yogyakarta
2. Cristiana. 2004. Kesehatan Reproduksi. Nuha Medika: Yogyakarta

3. Ellya Sibagariang, Eva dkk. 2010. Kesehatan Reproduksi Wanita.Jakarta: Trans Info Media

4. Kumalasari dan Andhyantoro. 2014. Kesehatan Reproduksi Untuk Mahasiswa Kebidanan dan Keperawatan. Jakarta: Salemba Medika

5. Mafhiasawah. 2010. Remaja Indonesia.http///:mafhiasawahbl ogspot.com. diunggah 02 Februari 2015 pukul: 23.22 WIB

6. Marmi. 2014.Kesehatan Reproduksi.Yogyakarta: Pustaka Belajar

7. Notoatmodjo, Soekidjo. 2010. Ilmu Perilaku Kesehatan. Jakarta: Rineka Cipta

8. Novita \& Fransiska. 2011. Promosi Kesehatan dalam Pelayanan Kebidanaan. Salemba Medika: Jakarta

9. Nugroho dan Indra. 2014. Masalah Kesehatan Reproduksi Wanita. Yogyakarta: Medical Book

10. Prayitno, Sunyoto. 2014. Buku Lengkap Kesehatan Reproduksi Wanita. Saufa:Yogyakarta

11. Ratnajuwita. Kesehatan Reproduksi

Remaja.http///:kebidanankitablog spot.com. diunggah 08 Desember 2014 pukul:1934 WIB

12. Setiawan \& Saryono. 2010. Metodologi Penelitian Kebidanan DIII, DIV, S1 dan S2. Nuha Medika: Yogyakarta 
13. Sintya Dewi, Nilda. 2012. Biologi Reproduksi.Yogyakarta: Pustaka Rihanna

14. Soetjiningsih. 2004. Tumbuh Kembang Remaja dan Permasalahannya. CV. Sagung Seto: Jakarta

15. Sufyan Asep. 2011. Biologi Reproduksi. PT. Refika Aditama

16. Ulfah Kurnia Dewi, Maria. 2013. Buku Ajar Kesehatan Reproduksi dan Keluarga Berencana untuk Mahasiswa Bidan. Jakarta: TIM

17. Wawan dan Dewi. 2010. Teori dan Pengukuran Pengetahuan, Sikap, dan Perilaku Manusia. Yogyakarta: Nuha Medika

18. Widyastuti, Yani dkk. 2009. Kesehatan

Reproduksi.Yogyakarta:

Fitramaya 